\title{
Correction to: Laboratory testing and numerical simulation of properties and thermal-induced cracking of Eibenstock granite at elevated temperatures
}

\author{
Fei Wang ${ }^{1}$ (D) Heinz Konietzky ${ }^{1} \cdot$ Thomas Frühwirt $^{1} \cdot$ Yajie Dai $^{2,3}$
}

Published online: 13 November 2021

(C) The Author(s) 2021

\section{Correction to: Acta Geotechnica (2020) 15:2259-2275 https://doi.org/10.1007/s11440-020-00926-8}

The article [Laboratory testing and numerical simulation of properties and thermal-induced cracking of Eibenstock granite at elevated temperatures], written by [Fei Wang, Heinz Konietzky, Thomas Frühwirt and Yajie Dai], was originally published Online First without Open Access. After publication in volume [15], issue [8], page [2259-2275] the author decided to opt for Open Choice and to make the article an Open Access publication. Therefore, the copyright of the article has been changed to (C) [The Author(s)] [2021] and this article is licensed under a Creative Commons Attribution 4.0 International License, which permits use, sharing, adaptation, distribution and reproduction in any medium or format, as long as you give appropriate credit to the original author(s) and the source, provide a link to the Creative Commons licence, and indicate if changes were made. The images or other third party material in this article are included in the article's Creative Commons licence, unless indicated otherwise in a credit line to the material. If material is not included in the article's Creative Commons licence and your intended use is not permitted by statutory regulation or exceeds the permitted use, you will need to obtain permission directly from the copyright holder. To view a copy of this licence, visit http://creativecommons.org/licenses/by/4.0/.

The original article has been corrected.

Funding Open Access funding enabled and organized by Projekt DEAL.

Open Access This article is licensed under a Creative Commons Attribution 4.0 International License, which permits use, sharing, adaptation, distribution and reproduction in any medium or format, as long as you give appropriate credit to the original author(s) and the source, provide a link to the Creative Commons licence, and indicate if changes were made. The images or other third party material in this article are included in the article's Creative Commons licence, unless indicated otherwise in a credit line to the material. If material is not included in the article's Creative Commons licence and your intended use is not permitted by statutory regulation or exceeds the permitted use, you will need to obtain permission directly from the copyright holder. To view a copy of this licence, visit http://creativecommons. org/licenses/by/4.0/.

Publisher's Note Springer Nature remains neutral with regard to jurisdictional claims in published maps and institutional affiliations.

The original article can be found online at https:// doi.org/10.1007/s11440-020-00926-8.

\footnotetext{
Fei Wang

fei.wang1@student.tu-freiberg.de

1 Geotechnical Institute, TU Bergakademie Freiberg, 09596 Freiberg, Germany
}

2 State Key Laboratory of Refractories and Metallurgy, Wuhan University of Science and Technology, Wuhan 430081, China

3 National-Provincial Joint Engineering Research Center of High Temperature Materials and Lining Technology, Wuhan 430081, China 